
\title{
25 Research Soure \\ Fluorescence of Ocular Surface in a Covid -19 Patient After Favipiravir Treatment: a Case Report
}

\section{Mehmet Ali Doran ( $\square$ malidoran75@gmail.com )}

Izmir Tepecik Training and Research Hospital: TC Saglik Bakanligi Izmir II Saglik Mudurlugu Izmir Saglik Bilimleri Universitesi Tepecik Egitim ve Arastirma Hastanesi https://orcid.org/0000-0003-1195-4830

\section{Hasan Aytogan}

Izmir Tepecik Training and Research Hospital: TC Saglik Bakanligi Izmir II Saglik Mudurlugu Izmir Saglik Bilimleri Universitesi Tepecik Egitim ve Arastirma Hastanesi

\section{Emre Ayintap}

Izmir Tepecik Training and Research Hospital: TC Saglik Bakanligi Izmir II Saglik Mudurlugu Izmir Saglik Bilimleri Universitesi Tepecik Egitim ve Arastirma Hastanesi

\section{Research Article}

Keywords: Fluorescence, Covid-19, Favipiravir, Ocular Surface, Ultraviolet light

Posted Date: April 8th, 2021

DOI: https://doi.org/10.21203/rs.3.rs-384224/v1

License: (c) (1) This work is licensed under a Creative Commons Attribution 4.0 International License. Read Full License

Version of Record: A version of this preprint was published at Virology Journal on July 13th, 2021. See the published version at https://doi.org/10.1186/s12985-021-01610-3. 


\section{Abstract}

\section{Background}

Favipiravir is used in treatment of Covid-19 patients. We aimed in this case report to share of ocular surface fluorescence in a patient after Favipiravir treatment.

\section{Case Presentation}

A 20 years-old male, with no medical history, applied to us with blurry vision and blue light reflection after Covid-19 treatment with Favipiravir. We observed bilateral fluorescence on his eyes and fluorescence of his nails. Biomicroscopic examination was insignificant.

\section{Conclusion}

We investigated the fluorescence of favipiravir tablets under ultraviolet light. Drug demonstrated fluorescence. We recorded the favipiravir fluorescence independently of the patient. This is strong evidence that the fluorescence of the patient's ocular surface and favipiravir are linked.

\section{Background}

The WHO declared the coronavirus outbreak caused by the novel coronavirus designated as severe acute respiratory syndrome coronavirus 2 (SARS-CoV-2) started at the end of 2019. The new coronavirus was named the "COVID-19 virus". [1] Before-after controlled trial, Favipiravir showed better treatment outcomes in COVID-19 patients in terms of their disease progression and viral clearance. [2] The results of systematic review and meta-analysis showed that patients had clinical and radiological improvements following the treatment with Favipiravir in comparison to that of the standard of care.[3] Favipiravir is currently being used in treatment of Covid-19 patients in Turkey. [4] We aimed in this case report to share of ocular surface fluorescence in a patient after Favipiravir treatment.

\section{Case Description}

A 20 years-old male ,with no medical history, applied to us with blurry vision and blue light reflection after Covid-19 treatment. He was a photographer and had Ultraviolet light (UVL) sources in his room. These complaints occured only under UVL. A nasopharyngeal swab reverse-transcription-polymerase chain reaction test was positive for Covid-19 and he was at second day of treatment of Favipiravir. He brought the photographs which was taken by himself under UVL. He took control photographs with his parents to determine that whether he was the only person affected from UVL. (Fig. 1) We evaluated the photographs and close-up photo which taken by himself. We observed bilateral fluorescence on his eyes. (Fig. 2-3) And fluorescence of his nails under the Wood's lamb examination.(Fig. 4) There is no fluorescence when used in the slit lamp biomicroscopy cobalt blue filter during examination. Biomicroscopic examination 
was insignificant. His visual acuity was $20 / 20$ bilaterally with Snellen Chart. İntraocular eye pressures were 16/17 mmhg. Anterior, posterior and angle optical coherence tomography findings were normal.

\section{Discussion}

Favipiravir is currently being used in treatment of Covid-19 patients in Turkey.[4] It is recommended $2 \times 1600 \mathrm{mg}$ for the first day and 2x600 mg Daily for the following four days. A recently published article demonstrated favipiravir induced nail and hair fluorescence.[5] In our literatüre search, we did not detect any case of ocular surface fluorescence. Here in, we reported the first case of ocular surface fluorescence in a patient under favipiravir treatment. In our examination, the patient did not show any fluorescence and visual impairment under room light and cobalt blue of a slit lamp which has 450-500 nm wavelength. Patient's UVL had 365-395 nm wavelength which can be reffered as UV-A. Ocular surface fluorescence disappeared after 14 days of favipiravir treatment but nail fluorescence was insisting. We investigated the fluorescence of favipiravir tablets under UVL under three different conditions.(Fig. 4A-B-C ). Firstly, whole drug was photographed, secondly, we siplitted the drug in two halves and thirdly we solved the drug in water. Drug demonstrated fluorescense under second and third condition. Thus, we recorded the favipiravir fluorescence independently of the patient. This is strong evidence that the fluorescence of the patient's ocular surface and favipiravir are linked.

\section{Conclusion}

We investigated the fluorescence of favipiravir tablets under UVL. Drug demonstrated fluorescence. We recorded the favipiravir fluorescence independently of the patient. This is strong evidence that the fluorescence of the patient's ocular surface and favipiravir are linked.

\section{Abbreviations}

UVL: Ultraviolet Light

\section{Declaration}

-Ethics approval and consent to participate

Not applicable (Case report)

-Consent to publication

An informed consent of patient and patient's parents was taken.

- Availability of data and material

Not applicable 
- Competing interests

No relevant financial or non-financial competing interests to report

- Funding

No funding to declare

- Authors' contributions

Mehmet Ali Doran : Collected the data, Designed the analysis, Performed the analysis, Wrote the paper

Hasan Aytogan : Collected the data, Designed the analysis, Performed the analysis, Wrote the paper

Emre Ayıntap : Collected the data, Designed the analysis, Performed the analysis

- Acknowledgements

Not applicable

\section{References}

1. "https://www.who.int/csr/don/12-january-2020-novel-coronavirus-china/en/ Accessed 5 Jul 2020.," [Online]. Available: https://www.who.int/csr/don/12-january-2020-novel-coronavirus-china/en/.

2. Q. Cai et al., "Experimental Treatment with Favipiravir for COVID-19: An Open-Label Control Study," Engineering, 2020, doi: 10.1016/j.eng.2020.03.007.

3. D. B. Shrestha, P. Budhathoki, S. Khadka, P. B. Shah, N. Pokharel, and P. Rashmi, "Favipiravir versus other antiviral or standard of care for COVID-19 treatment: a rapid systematic review and metaanalysis," Virol. J., 2020, doi: 10.1186/s12985-020-01412-z.

4. Https://covid19.saglik.gov.tr/TR-66926/eriskin-hasta-tedavisi.html and A. 20 J. 2020, "Https://covid19.saglik.gov.tr/TR-66926/eriskin-hasta-tedavisi.html 2020, Accessed 20 Jul," vol. 19, 2020, [Online]. Available: https://covid19.saglik.gov.tr/TR-66926/eriskin-hasta-tedavisi.html.

5. M. Aslan Kayıran, F. Cebeci, V. A. Erdemir, H. Aksoy, N. Akdeniz, and M. S. Gürel, "Fluorescence of nails and hair on Wood's lamp examination in Covid pandemic; undefined effect of Favipiravir in humans," Dermatol. Ther., vol. n/a, no. n/a, p. e14740, doi: https://doi.org/10.1111/dth.14740.

\section{Figures}




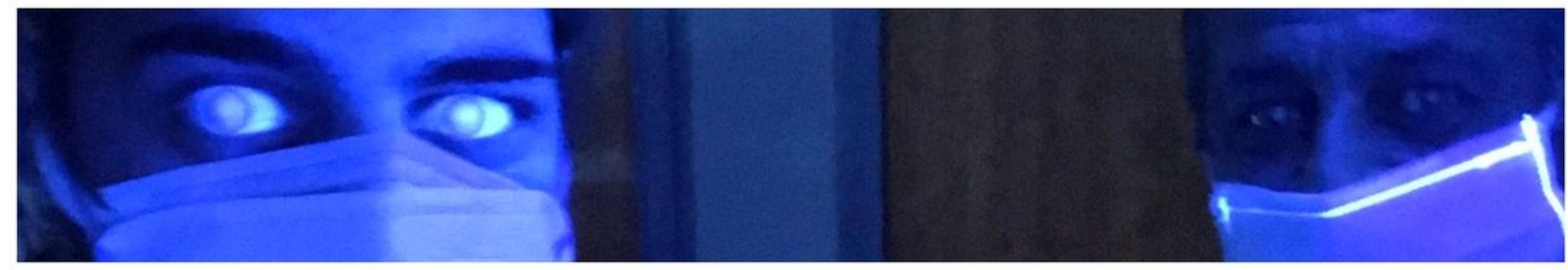

\section{Figure 1}

Fluorescence of ocular surface after Favipiravir treatment in the patient (Left Side). Different appearance of patient's eyes in the same environment with his father under ultraviolet light

\section{Figure 2}

Bilateral fluorescence of eyes under ultraviolet light 


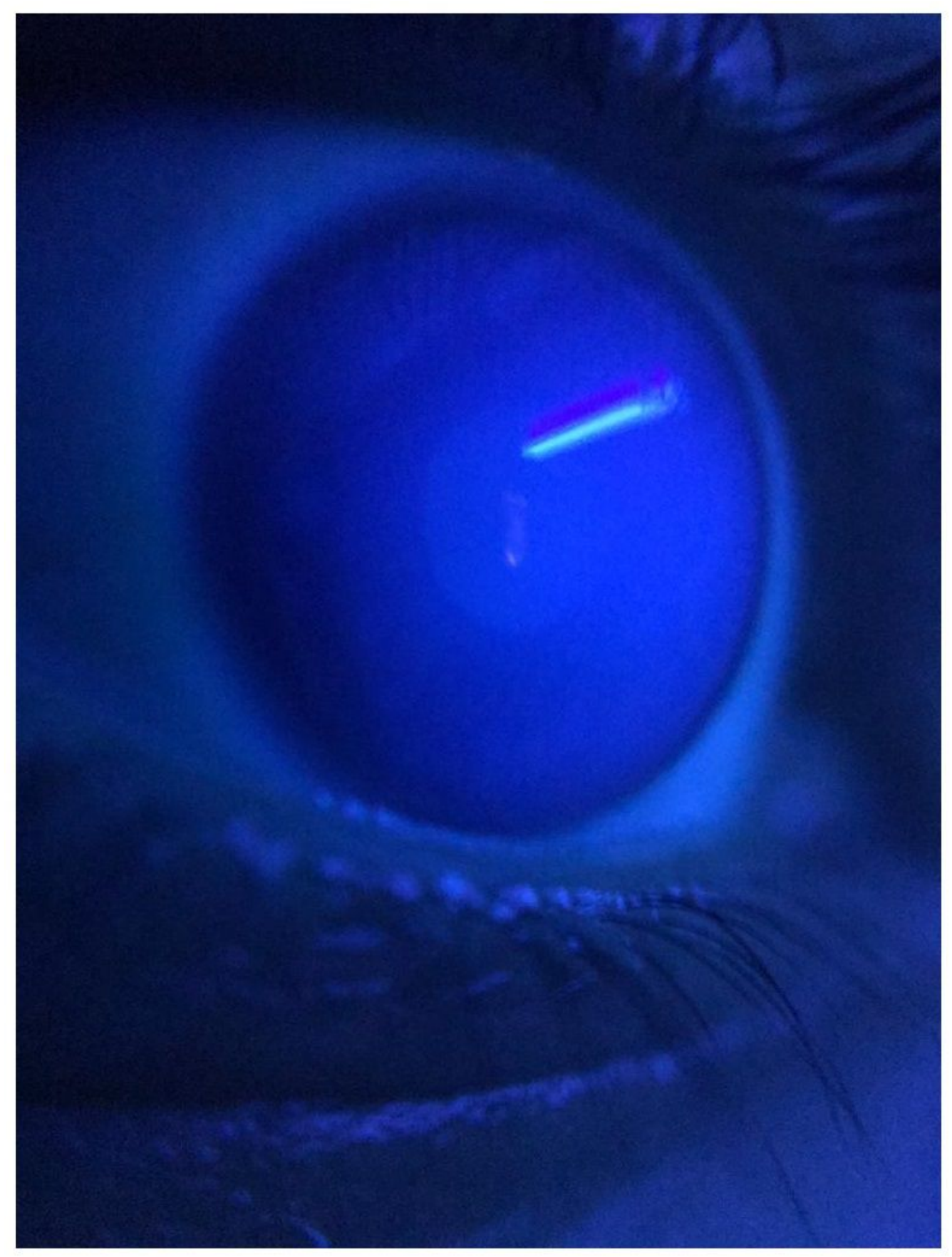

Figure 3

Close-up photograph of the patient's eye; Fluorescence on the entire ocular surface and ultraviolet light reflex in the central cornea. 
A

\section{B}

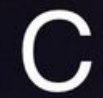

\section{Figure 4}

(A) Whole drug (B) The drug in two halves (C) Solved drug in water 